\title{
Assessment of Land-Use and Land Cover Change Effect on Melka Wakena Hydropower Dam in Melka Wakena Catchment of Sub-Upper Wabe-Shebelle Watershed, South Eastern Ethiopia
}

\author{
Hussein Hayicho*, Mersha Alemu, Haji Kedir \\ Department of Geography and Environmental Studies, Madda Walabu University, Bale Robe, Ethiopia \\ Email: *hussienhayicho2000@gmail.com
}

How to cite this paper: Hayicho, H., Ale$\mathrm{mu}$, M. and Kedir, H. (2019) Assessment of Land-Use and Land Cover Change Effect on Melka Wakena Hydropower Dam in Melka Wakena Catchment of Sub-Upper Wabe-Shebelle Watershed, South Eastern Ethiopia. Agricultural Sciences, 10, 819-840. https://doi.org/10.4236/as.2019.106063

Received: January 10, 2019

Accepted: June 27, 2019

Published: June 30, 2019

Copyright $\odot 2019$ by author(s) and Scientific Research Publishing Inc. This work is licensed under the Creative Commons Attribution International License (CC BY 4.0).

http://creativecommons.org/licenses/by/4.0/

\begin{abstract}
Land degradation and sedimentation has been increasingly a crucial problem in upper Wabe-Shebele catchment, south eastern Ethiopia over the last two decades. Nevertheless, so far no detail research has been conducted to assess such problem. Therefore, the present study was conducted at Melka Wakena Catchment of Upper Wabe Shebelle Watershed to identify the trends of land use and land cover change and its effects on hydrology and land degradation. To achieve the objectives of the study different data sources such as satellite images, climate and rivers gage data; soil sample data were collected and analyzed using relevant corresponding up to dated software. Based on pre-defined criterion, available satellite images for the years 1986, 2011, and 2015 were analyzed using ERDAS, ENVI and ArcGIS softwares. The study catchment stream flow and soil erosion information were computed using SWAT model. MUSLE was employed to assess the amount of sediment yields and rate of soil loss existed in the study area. The study showed that significant land use and land cover changes were recorded during the past nearly three decades. This change has been directly affecting the hydrology and sedimentation of the catchment. The annual surface runoff varied between $45.65 \mathrm{~mm}$ and $332.29 \mathrm{~mm}$. The amount of surface runoff was generally increased from 1990 to 2010, whereas decreased until 2013 before beginning the increasing trend. The result of the sediment yield analysis showed that there was a general increasing trend from 1992 to 2010 and then declined up to 2013 before it started the rising trend. From the simulated results, it was observed that the long-term mean soil loss was $20.22 \mathrm{t} / \mathrm{ha}$. Sustainable inte-
\end{abstract}


grated watershed management practices should be practically implemented throughout the landscape of the catchment from upper to down streams. Above all, dam buffer area needs to be demarcated and protected from the current settlement: cultivation and over grazing.

\section{Keywords}

Land Use/Land Cover, Soil Erosion, Sedimentation, Melka Wakena, Ethiopia

\section{Introduction}

Land degradation signifies the temporary or permanent decline in the productive capacity of the land resources ecosystem such as soil, water, vegetation, rocks, air, climate, relief [1]. It is caused by wrong land management practices of human interferences in the natural ecosystems [2] [3]. Ethiopia is one of the well-endowed countries in Sub-Saharan Africa in terms of natural resources and valuable diversity production in the environment. However, land degradation is a threat to its natural resources for centuries. Inappropriate use of land for agriculture and poor management of its ecosystem coupled with high population pressure relying on natural resources leads to environmental problems such as land degradation through accelerated soil erosion and downstream sedimentation [4].

Sedimentation as an ecological and environmental phenomenon is increasingly affecting the sustainable development of human societies in the Ethiopian highlands [5]. Such land degradation and soil erosion from high lands of the country have attributed to increased soil nutrient loss (on-site effect) and sedimentation of dams and lakes (off-site effect) [6]. Dams provide multifaceted purposes to the socio-economic development of a nation through irrigation in agriculture and generation of hydro-electric power in the supply of energy. However, due to environmental phenomenal happening and persistent human action in the country, our dams are facing problems in relation to siltation, landslides and degradation and nutrient accumulation [7]. Similarly, there is an increasing problem of land degradation in Melka Wakena catchment and sedimentation problem of the dam in the last two decades. In Ethiopia, fewer studies [5] [8] [9] [10] disclosed the effect of land degradation by soil erosion and sedimentation on reservoirs providing hydro-electric power and irrigation water. In line with this, there are limited such studies in south eastern part of Ethiopia in general, for sub-basins of upper Wabe Shebele catchment which drains to Melka Wakena hydro-electric dam in particular. Therefore, a study on the trends, rate and effects of land degradation and sedimentation at sub-catchment level is crucial for the formulation and implementation of realistic integrated watershed management intervention strategies that ensure the prolonging useful life span of reservoirs as well as the improvement of local ecosystem services and local li- 
velihoods.

Predictions of long-term impacts of land-cover change on streamflow are important to study different environmental conditions. For this purpose Soil and Water Assessment Tool (SWAT) is one of the most suitable models for simulating water and sediment yields under land use and management scenarios [11]. Thus, this study aims to assess the influence of land-use change on the stream flow through GIS and remote sensing techniques coupled with the SWAT model.

Therefore, this land degradation problems aforementioned of the catchment call for catchment based assessment on the key impacts of land degradation /land use and land cover change on hydrology in order to plan for catchment based integrated watershed management approaches that reduce runoff and sedimentation from the catchment so as to ensure the sustainable function of hydroelectric power production of the dam. The aims of this study therefore were 1) to evaluate the spatio-temporal trends of land use and land cover changes over the last four decades, 2) to identify the effects of land degradation/land use and land cover change on sediment yield in the catchment; 3 ) to analyze the status of sediment yield into Melka Wakena reservoir from the catchment.

\section{Study Area}

\subsection{Description of the Study Area}

The study catchment is located between $6.5^{\circ}$ and $7.5^{\circ}$ north latitude and $39^{\circ}$ $39.7^{\circ}$ east longitude, in West Arsi zone, Oromia regional state. The total area of the catchment is $4280 \mathrm{~km}^{2}$.

The mean annual temperature of the study catchment is found between $2^{\circ} \mathrm{C}$ $15^{\circ} \mathrm{C}$ in the higher altitude areas and $16^{\circ} \mathrm{C}-24^{\circ} \mathrm{C}$ in the lower plateau areas. The study catchment is classified into two agro-climatic regions: the warm temperate/ baddadaree/ and cool temperate/Badda/ covering $24 \%$ and $76 \%$ of the total the area, respectively. For most of the areas, the main rainy season starts in June and extends to July and August and also continues up to September in some higher area. The mean annual rainfall of the study area ranges from $1200 \mathrm{~mm}$ to 2940 $\mathrm{mm}$. The intensity and duration of rainy days and seasons varies from the warm temperate and cool temperate and this number slightly decreases as one goes down to the kolla areas along Wabe river course after the dam.

Geological survey shows that the relief of the study catchment is characterized by plain, hilly, valley and gorges, highest peaks and dissected plateaus. The mean elevation of the watershed is $2911 \mathrm{~m}$ with maximum of 4322/4215 m (Kaka mountains peaks) and minimum elevation is $2350 / 2143 \mathrm{~m}$ above sea level which is found near the Melka-Wakena dam substation. The catchment is naturally endowed with many rivers and streams as well as with one artificial lake. The study catchment is drained by intermittent and perennial rivers like Wabe, Negesso, Maribo, Furuna, Wekentera, Uruba, Ubultoand Debara and Melka Wekena dam (Figure 1). 


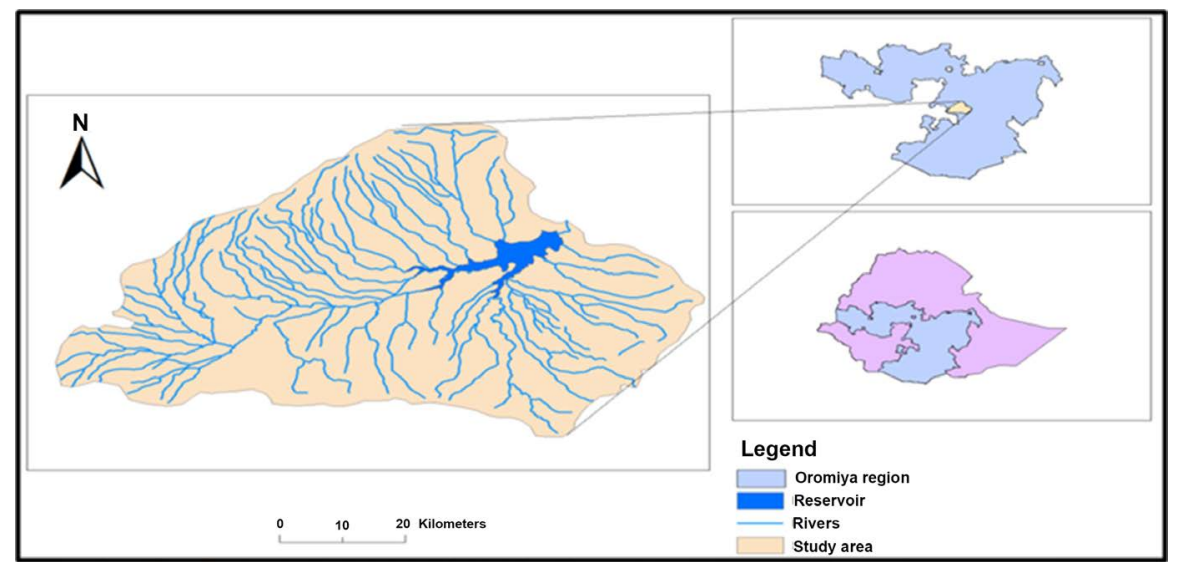

Figure 1. Melka Wakena catchment (national, regional and zonal location of study catchment).

The study area is characterized by a wide range of soil types. The dominant soils in the study catchment are Vertisols, Chernozems, Cambisols, Luvisols, Nitosols. The nature and distribution of the vegetation of these districts ranges from wooded grassland to afro-alpine. Alpine, Afro and sub Afro-Alpine vegetation is found in the area above $3100 \mathrm{~m}$ sea level of the area. Abundant low bush taught grasses and lichens are common species on the top of the mountain where temperature is very low. Below the Afro Alpine and sub Afro-Alpine broad leafed forests which are dominated by Juniperus, Podocarpus, hagenaAbyssinica tree species as well as shrub and bush which highly dominated by "Asta"/Erica species are found parts of Adaba and Dodola districts.

The diverse climate and topographic phenomenon have provided a wide range of natural environments, which form favorable habitat for a wide variety of fauna in study catchment. The local inhabitants rely on the forest to supply most of their needs, mainly fuelwood, pasture, timber, wild fruits and medicinal herbs.

\subsection{Socio-Economic Characteristics}

According to the projection made from the 2007 Population and Housing census, the total population of the study catchment was 496,768 in the year 2014.E.C. with population density of about 137.33 persons $/ \mathrm{km}^{2}$, the highest than the national average (84 persons $/ \mathrm{km}^{2}$ ) [12]. Agriculture is the main livelihood base and economy of the study catchment. Like other parts of the Ethiopian highlands, the major farming system is mixed cereal-livestock. The cool and the sub-tropical climatic condition of the study catchment make the districts suitable for the production of major cereals crops such as Teff, Wheat, Barley and Maize. Of these, wheat covers the largest portion of cultivated land. Chickpeas, Nudge, Linseed are legumes crops grown in the zone. Farmers use crop rotation, animal's dung, fallowing to maintain soil fertility and yield. Soil banding, seedling plantation, Terracing, check dam and land rehabilitation are among Soil and 
Water Conservation practices in study catchment. Rearing animals serve for a variety of purposes including food, draught power, transport, manure and skin. Modern livestock extension package of dairy and beef farms development were not well introduced and well adapted in the area, particularly in the rural areas. There is a gradual declining of pastureland and consequently declining the quantity and quality of livestock due to the expansion of farmland at the expense of grazing land.

The ever increasing price of agricultural inputs (chemical fertilizer, improved seeds, insecticides and herbicides), expansion of weeds; soil erosion due to improper farming practices, and waterlogging were major agricultural problems that attributed to low agricultural production and productivity in study catchment.

\subsection{Methods and Materials}

The research design was based on methodologies involving GIS, remote sensing (land use/land cover change) tools, SWAT model (hydrological, modeling), Analysis and understanding of these each case helps to identify and propose/promote best integrated watershed management approaches in the study catchment.

\subsubsection{SWAT Model}

The Soil and Water Assessment Tool (SWAT) is a comprehensive, semi-distributed river basin model that requires a large number of input parameters, which complicates the model parameterization and calibration. It is also one of the most suitable models for simulating streamflow under land use and management scenarios [13]. SWAT operates on daily time step and uses input data such as physiographical (elevation, land use and soil properties), meteorological and, hydrological data. The SWAT system embedded within GIS can integrate various spatial environmental data, including information about soil, land cover, climate and topographical features. It also provides the necessary information for the treatment of the catchments into sub catchments (sub-basins) which have their own indicators and interrelationship among them.

In SWAT, once the watershed of interest is divided into sub basins, they are then further subdivided into HRUs that consist of homogeneous land use, management, and soil characteristics. These elements give the model the strength to better represent the properties of land uses and/or soils of each sub basin that have significant effect on its hydrology. For a study such as the present one, this capability of SWAT helps to analyze surface runoffs, base flows, ETs and groundwater recharge from different land use/land cover and soil types. It can also be used to analyze the effects of various land management practices on land degradations. In this study, a single HRU for each sub basin option that is 17 HRUs for 17 sub basins before reclassifying the sub basins in seven sub basins was considered. Full hydrologic balance of each HRU includes accumulation and 
evaporation of the plants, determination of effective rainfall, water exchange between surface runoff and soil layer, water penetration into deeper layers, evapo-transpiration, sub-surface flow and underground flow and water accumulation were also considered. Flow generation, sediment yield, and nonpoint-source loadings from each HRU in a sub watershed were summed, and the resulting loads were routed through channels, ponds, and/or reservoirs to the watershed outlet. The various hydrological processes that move precipitation to stream flow, discussed above, are either described by differential equations governing the hydraulic/hydrological laws within the various compartments of the hydrological cycle or, for sake of simplicity, by semi-empirical algebraic equations with some tunable parameters [14]. No matter what type of problem being studied by SWAT, water balance is the driving force behind everything that happens in the watershed. In order to achieve precise forecast of circulation of the pesticides, sediments or nutrients, hydrologic cycle is simulated by the model which integrates overall water circulation in the catchment area. Hydrologic simulations in the catchment area can be divided into two groups. In the soil phase of the hydrologic cycle the processes on the surface and in the sub-surface soil occur, as well as the circulation of sediments, nutrients and pesticides through the water flow finally sub-catchments. In the second phase, the circulation of water and sediment through the river network up to the exit profile are observed. The hydrologic component of SWAT partitions precipitation into four control volumes: 1) the surface, 2) the soil profile or root zone, 3) the shallow aquifer, and 4) the deep aquifer. The fundamental hydrology of a watershed in SWAT is based on the following water balance Equation (1).

$$
S W_{t}=S W_{0}+\sum_{t=0}^{t}\left(R_{\text {day }}-Q_{\text {surf }}-E_{a}-W_{\text {seep }}-Q_{g w}\right)
$$

where $S W$ is the final soil water content (mm water), $S W_{0}$ is the initial soil water content on day $i$ (mm water), $t$ is the time (days), $R_{d a y}$ is the amount of precipitation on day $i$ ( $\mathrm{mm}$ water), $Q_{\text {sur }}$ is the amount of surface runoff on day $i(\mathrm{~mm}$ water), $E_{a}$ is the amount of evapo-transpiration on day $i$ ( $\mathrm{mm}$ water), $W_{\text {seep }}$ is the amount of water entering the vadose zone from the soil profile on day $i$ (mm water), and $Q_{g w}$ is the amount of return flow on day $i$ (mm water). The subdivision of the watershed enables the model to reflect differences evapo-transpiration for various crops and soils. Runoff is predicted separately for each HRU and routed to obtain the total runoff for the watershed. This increases accuracy and gives a much better physical description of the water balance [15].

To estimate surface runoff two methods are available. These are the curve number procedure USDA Soil Conservation Service and the Green \& Ampt infiltration method. In this study, the SCS curve number method was used to estimate surface runoff. Hargreaves method was used for estimation of potential evapo-transpiration (PET). The SCS curve number is described by Equation (2). 


$$
Q_{\text {surf }}=\left(\frac{R_{d a y}-0.25}{R_{d a y}+0.85}\right)^{2}
$$

in which, $Q_{\text {surf }}$ is the accumulated runoff or rainfall excess $(\mathrm{mm}), R_{d a y}$ is the rainfall depth for the day $(\mathrm{mm}), S$ is the retention parameter $(\mathrm{mm})$. The retention parameter is defined by Equation (3).

$$
S=25.4\left(\frac{100}{C N} 10\right)
$$

The SCS curve number is a function of the soil's permeability, land use and antecedent soil water conditions. SCS defines three antecedent moisture conditions: 1-dry (wilting point), 2-average moisture, and 3-wet (field capacity).

The moisture condition 1 curve number is the lowest value that the daily curve number can assume in dry conditions. The curve numbers for moisture conditions 2 and 3 are calculated from Equations (4) and (5).

$$
\begin{gathered}
C N_{1}=C N_{2}-\frac{20 \cdot\left(100 \cdot C N_{2}\right)}{\left(100-C N_{2}+\exp \left[2.533-0.0636 \cdot\left(100-C N_{2}\right)\right]\right)} \\
C N_{3}=C N_{2} \exp \left[0.00673 \cdot\left(100-C N_{2}\right)\right]
\end{gathered}
$$

in which $C N_{1}$ is the moisture condition 1 curve number, $C N_{2}$ is the moisture condition 2 curve numbers and $\mathrm{CN}_{3}$ is the moisture condition 3 curve numbers. Typical curve numbers for moisture condition 2 are listed in various tables which are appropriate to slope less than $5 \%$. But in the study catchments there are areas with slopes greater than $5 \%$. To adjust the curve number for higher slopes an equation was used (Equation (6)).

$$
C N_{25}=\frac{\left(C N_{3}-C N_{2}\right)}{3} \cdot[1-2 \cdot \exp (-13.86 \cdot s l p)]+C N_{2}
$$

in which $\mathrm{CN}_{2} S$ is the moisture condition 2 curve number adjusted for slope, $\mathrm{CN}_{3}$ is the moisture condition 3 curve numbers for the default $5 \%$ slope, $C \mathrm{~N}_{2}$ is the moisture condition 2 curve numbers for the default $5 \%$ slope, and slop is the average percent slope of the sub-basin. The peak runoff rate, the maximum runoff rate that occurs with a given rainfall event, is an indicator of the erosive power of a storm. It is used to predict sediment loss. SWAT calculates peak runoff rate with a modified rational method which is given as:

$$
\text { qpeak }=\frac{C \cdot i \cdot \text { Area }}{3.6}
$$

where, qpeak is the peak runoff rate $\left(\mathrm{m}^{3} / \mathrm{s}\right), C$ is the runoff coefficient, $i$ is the rainfall intensity $(\mathrm{mm} / \mathrm{h})$, Area is the sub basin area $\left(\mathrm{km}^{2}\right)$ and 3.6 is a unit conversion factor from $(\mathrm{mm} / \mathrm{h})\left(\mathrm{km}^{2}\right)$ to $\mathrm{m}^{3} / \mathrm{s}$.

The SWAT model employs the modified Universal Soil Loss Equation (MUSLE) developed by [16] to compute sediment yield for each sub-basin. MUSLE is a modified version of the Universal Soil Loss Equation (USLE) developed by [17] [18]. The MUSLE is given as: 


$$
\text { sed }=11.8 \cdot\left(Q_{\text {surf }} \cdot \text { qpeak } \cdot \text { area }_{\text {hru }}\right)^{0.86} \cdot K_{U S L E .} \cdot C_{U S L E} \cdot P_{U S L E} \cdot L S_{U S L E} \cdot C F R G
$$

where, sed is the sediment yield on a given day $(t), Q_{s u r}$ is the surface runoff volume $(\mathrm{mm} / \mathrm{ha})$, qpeak is the peak runoff rate $\left(\mathrm{m}^{3} / \mathrm{s}\right)$, area ${ }_{h r u}$ is the area of the $H R U(\mathrm{ha}), K_{U S L E}$ is the USLE soil erodability factor, $C_{U S L E}$ is the USLE cover and management factor, $P_{U S L E}$ is the USLE support practice factor, $L_{S U S L E}$ is the USLE topographic factor and $C F R G$ is the coarse fragment factor.

The SWAT model allows for simultaneous computations on each sub-basin and routes the water, sediment and nutrients from the sub-basin outlets to the basin outlet. The routing model consists of two components-deposition and degradation, which operate simultaneously. The amount of sediment finally reaching the basin's outlet, SOUT, is given as:

$$
S_{\text {OUT }}=S_{I N}-S_{D}+D_{T}
$$

where, $S_{I N}$ is the sediment entering the reach, $S D$ is the sediment deposited and $D_{T}$ is total degradation. The total degradation is the sum of re-entrainment and bed degradation components, and it is given as:

$$
D_{T}=\left(D_{r}+D_{B}\right)\left(1-D_{R}\right)
$$

where, $D_{r}$ is the sediment re-entrained, $D_{B}$ is the bed material degradation component and $D_{R}$ is the sediment delivery ratio. Detailed theoretical documentation for the model is given by [19].

\subsubsection{SWAT Input Data and Their Sources}

The following sources were used to provide the input data for SWAT:

Digital Elevation Model (DEM): A Digital Elevation Model (DEM) gives the elevation, slope and defines the location of the streams network in a basin. A DEM with a spatial resolution of $30 \mathrm{~m}$ by $30 \mathrm{~m}$ was used in this study and it was obtained from the International Centre for Research in Agroforestry (ICRAF).

Land use/Land Cover data/Map: Three series of satellite land sat images (1986, 2011, \& 2015) were used to analyze the extents and trends of land use/cover changes and their subsequent effects on hydrological processes and land degradation in the study catchment. These images were downloaded at free of charge from United States Geological Survey (USGS) website http://www.usgs.gov. All images were selected for analyses from the end of the dry season (January and February). In order to enhance the quality of the image and readability of the features, series of pre-processing steps such as geometric correction, georeferencing, image enhancement were employed. The land use/land cover data combined with the soil cover data generates the hydrologic characteristics of the basin or the study area, which in turn determines the excess precipitation, recharge to the groundwater system and the storage in the soil layers.

Soil Map and data: The soil data as required by SWAT to predict the stream flow should include the relevant hydraulic conductivity properties: the soil bulk density, the saturated hydraulic conductivity and the soil available water capacity (SOL_AWC). The soil data was obtained from the Internet (ISRIC website), the 
parameters of the soil such as the Soil Bulk Density $(\mathrm{g} / \mathrm{cc})$, Saturated Hydraulic Conductivity, Ks $(\mathrm{mm} / \mathrm{hr})$ and Soil Available Water Capacity were missing and were estimated using a hydrology programme called the Soil Water Characteristics which was downloaded from the Internet.

Stream Flow data: The hydrological processes included in the SWAT model are evapo-transpiration, surface runoff, infiltration, percolation; shallow and deep aquifers flow, and channel routing [20]. These hydrological discharge data was collected from the Ministry of Water, Irrigation, and Energy of Ethiopian. Normally; these daily flows from the river gauge at the outlet of the study catchment were used for calibration and validation of the simulated flows and sediment yield.

Weather data: The meteorological data of Adaba, Dodola, Melka Wakena, Kofale and Assasa stations were collected from National Meteorological Agency of Ethiopian for the period of 1987-2014. The main meteorological parameters needed to be collected are minimum-maximum temperature and precipitation. The other parameters like wind speed, relative humidity and sunshine hours were generated using WXGEN model that is embedded in the SWAT.

\section{Result and Discussions}

\subsection{Status of LULC Changes}

The Land use/Land cover maps of Melka Wakena catchment (Figure 2) clearly showed that there were variations in land use/land cover types in the last 30 years. The 1986 image classification results showed that the moderate cultivation coverage (34\%) was the dominant land cover while the grassland areas (15\%) were the least coverage of the catchment. The remaining parts of the catchment were composed of intense cultivation (33\%) and forest land (18\%). From 2011 image classification, both intense and moderate cultivation were reduced by $4 \%$ and $3 \%$ respectively from their coverage in 1986 . On the hand, grassland coverage increased by $8 \%$ while forest land coverage was declined to $15 \%$ in the catchment. In land use/land cover classes of the 2015 image, intense cultivation and grassland resulted in further decrease to $29 \%$ and $19 \%$ respectively. However, the other two classes, moderate cultivation and forest land showed an increase of $2 \%$. Out of the total area, $2 \%$ in 2011 and 3\% in 2015 have been occupied by reservoir and major towns of the watershed.

\subsection{Land Use/Land Cover Changes Detection}

Land use/land cover change detection involves detecting the nature of changes that have occurred, estimating its extents, and analyzing spatial patterns of the changes [21]. From the above three times satellite image classification and it can be observed that both land use/land cover changes and modifications of the classes have been identified. Similarly, the extent of this land and land cover change or modification in Melka Wakena Catchment in the last 30 years was also shown in Table 1. 


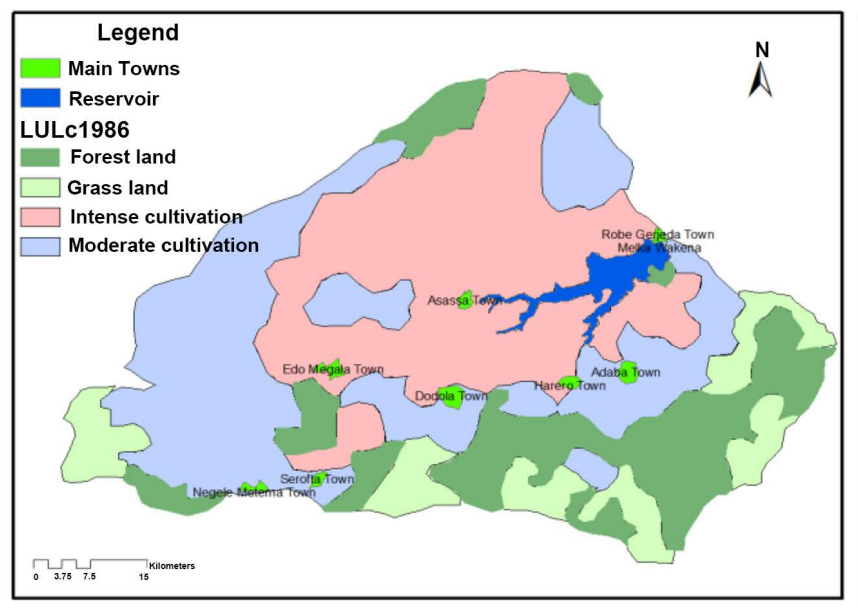

(a)

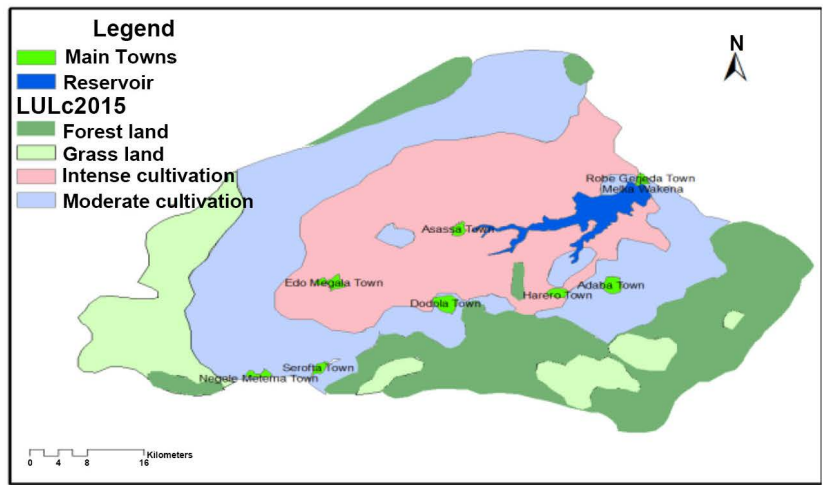

(c)

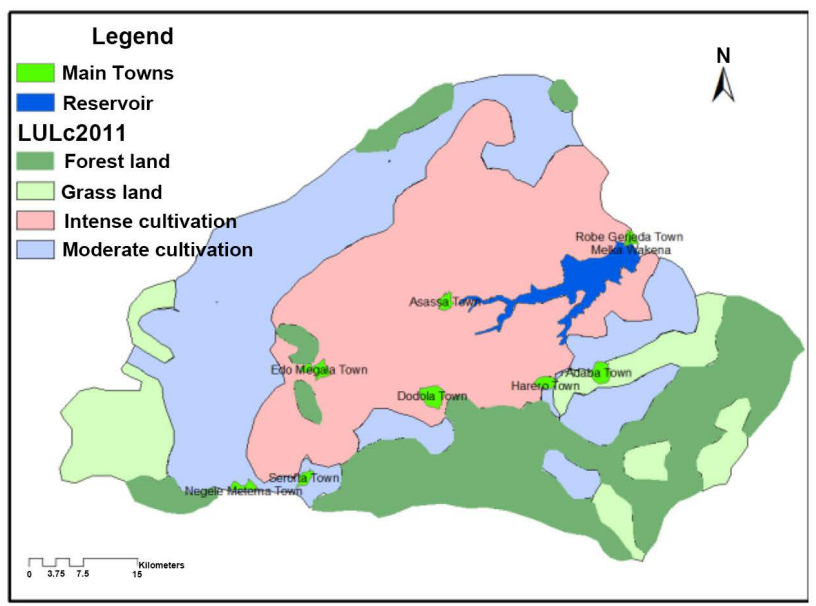

(b)

Figure 2. LULC types of Melka Wakena (1986a, 2011b, and 2015c).

Table 1. Extent of LULC in different study periods (1986, 2011 and 2015).

\begin{tabular}{ccccccc}
\hline \multicolumn{7}{c}{ Area of land use/land cover of study catchments- } \\
\hline \multirow{2}{*}{ Land use/cover classes } & \multicolumn{2}{c}{ 1986 Area } & \multicolumn{2}{c}{ 2011 Area } & \multicolumn{2}{c}{ 2015 Area } \\
\cline { 2 - 8 } & $\mathrm{Ha}$ & $\%$ & ha & $\%$ & Ha & $\%$ \\
\hline Intense cultivation & 139,300 & 33 & 123,100 & 29 & 118,400 & 28 \\
Moderate cultivation & 145,300 & 34 & 130,900 & 31 & 137,800 & 33 \\
Forest land & 75,100 & 18 & 63,300 & 15 & 71,800 & 17 \\
Grass land & 62,700 & 15 & 97100 & 23 & 78,900 & 19 \\
\hline
\end{tabular}

In general when the changes between 1986 and 2011 are compared, the major changes were in forest and grasslands while some areas of cultivations were engulfed by expansions of the towns in the catchment. Out of the total changes to forest lands, the majority of them were converted to grasslands. However, in the years between 2011 and 2015, some plantations were observed to raise the forest covers by $1 \%$ while the decline in grasslands and modifications of the intense 
cultivations contributed to increase moderate cultivations.

This time was in aligning with the provision of 100 hectars of the state farms (intense cultivation) to some kebeles/villages in both Dodola and Adaba districts. However, this amount of land left for the kebeles/villages was too insignificant as compared to the amount of lands that had been taken from them for state farms and hydroelectric power generations.

\subsection{The Effects of LULCC on Hydrology and Land Degradations}

The effects of land use/land cover change on hydrologic factors are manifested at different spatial and temporal scales. These changes are observed to affect soil and water, biodiversity and microclimate conditions of a given catchment [22]. Particular to hydrologic aspects, the land use and land cover type can affect both the infiltration and runoff amount by following mostly the declines of rainfalls [23]. In turn, the runoff of catchment determines the amount of sediment yields, rate of soil loss and erosion and collectively the land degradation of the catchment. Therefore, based on the simulation results, these effects on water yields and sediment yields of the study area at different levels of conceptualization with respect to space and time are discussed below. To clearly observe the impacts and distribution of surface runoff (SURQ), it is often advisable to assess along with groundwater flow (GWQ) and catchment water yields.

The effects of land use and land cover changes described above were observed affecting directly the surface runoff and water yields of the catchment which drive both landscape and channel sedimentations. Accordingly, the mean annual surface runoff from the entire watershed ranged from $45.65 \mathrm{~mm}$ in 2002 to $332.29 \mathrm{~mm}$ in 2010 , with a mean of $175.16 \mathrm{~mm}$.

The Surface runoff generated showed an increasing trend (Figure 3 ) which is similar to that of the rainfall. During simulation, at least two years (1986 and 1987) of warming up was considered by SWAT model. From the analysis of rainfall data, it was observed that the surface runoff of the catchment was highly dependent on the amount and distribution of the rainfalls within and the surrounding highlands.

The relationship between runoff and rainfall in the catchment can be expressed by the power function that showed the best fit curve, and rainfall variability explained about 96 percent of the variance in surface runoff (Figure 4).

The Melka Wakena catchment was subdivided into seven sub basins based on the watershed characteristics (Table 2). Normally, the hydrologic processes are simulated at HRU level which has unique land use, soil, and slope combinations. These HRUs are then combined to get and describe the hydrologic components of each sub basins.

Surface runoff, base flow and water yields from each sub-basin were estimated for the period 1986-2015. Figure 5 presents the long-term mean annual surface runoff from the seven sub basins. Hence, at this scale, the annual surface runoff varies between $21.88 \mathrm{~mm}$ and $141.68 \mathrm{~mm}$ (Figure 6). The high values of surface 


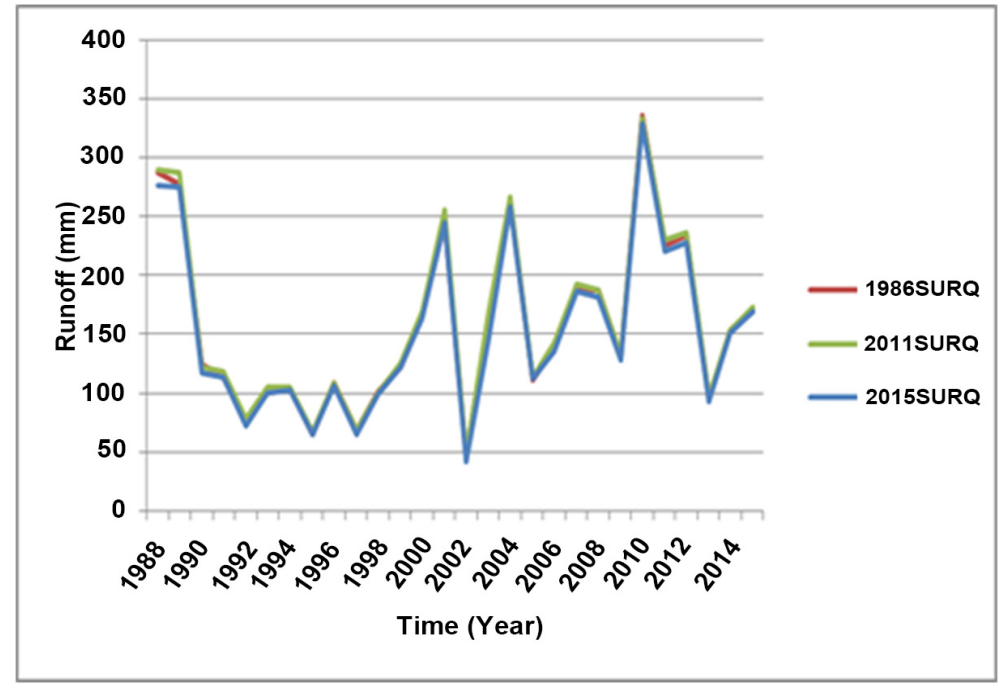

Figure 3. Temporal pattern of mean annual runoff (1986-2015).

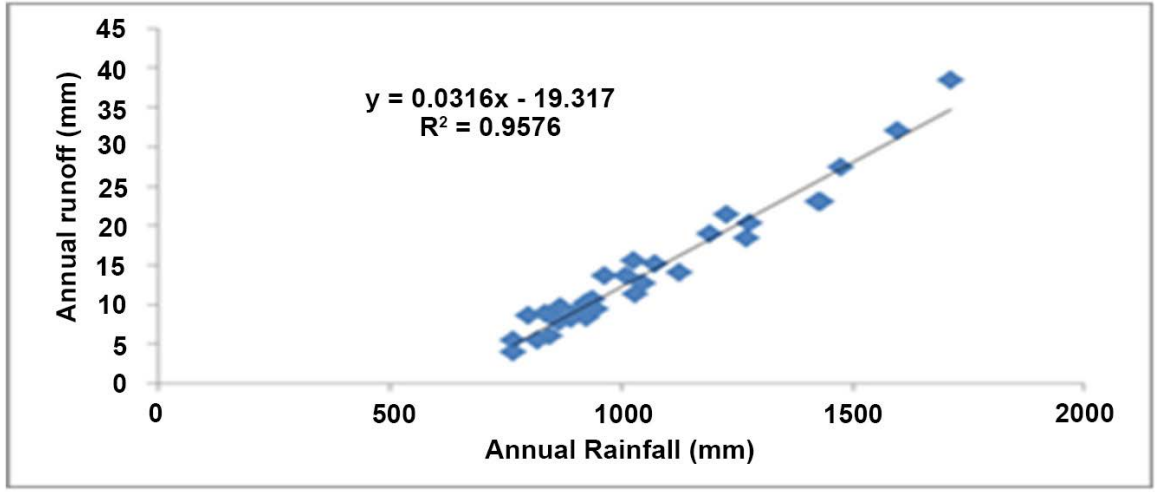

Figure 4. Relationship b/n annual rainfall and surface runoff.

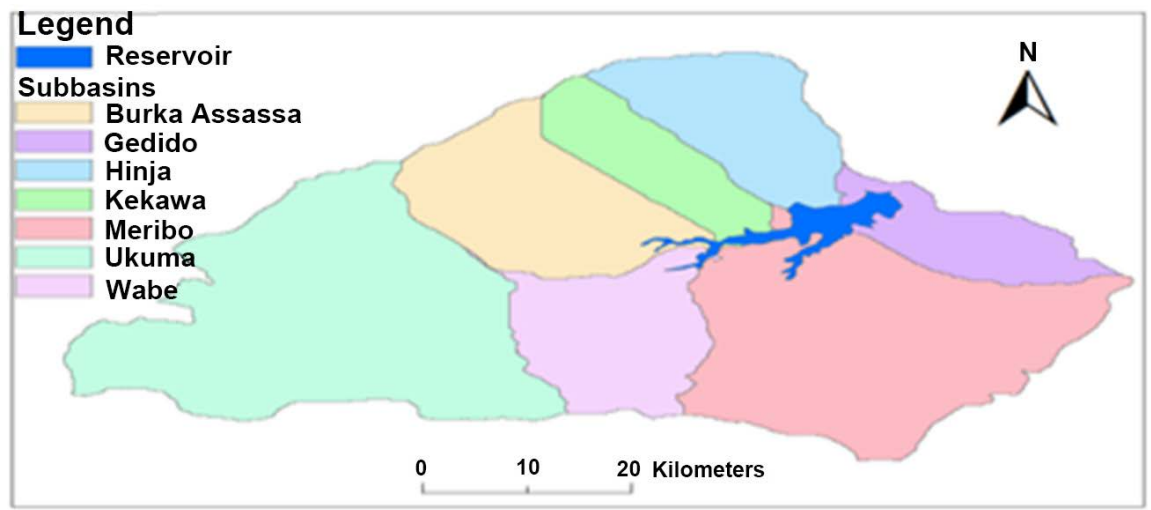

Figure 5. Sub-basins of the Melka Wakena catchment (2015).

runoff were estimated in sub10 (subbasin10) in which clay and clay loam soil classes are the dominant soil types. The dominant land use in this sub basin is cultivation (both intense and moderate) and the slope of the majority of the area range from $0 \%$ to $10 \%$. From hydrologic soil group perspective, the soil class of 
Table 2. Basic physical characteristics of Melka Wakena sub basins.

\begin{tabular}{|c|c|c|c|c|}
\hline Sub basin Name & Area $\left(\mathrm{km}^{2}\right)$ & $\begin{array}{c}\text { Dominant Land use/land cover of } \\
\qquad 1986 / 1999 / 2011\end{array}$ & Dominant soil & $\begin{array}{l}\text { Dominant } \\
\text { slope }\end{array}$ \\
\hline Subbasin 1 & 388 & $\begin{array}{l}\text { Intense Cultivation, Forest/Intense } \\
\text { and moderate cultivation/Intense and } \\
\text { moderate cultivation }\end{array}$ & $\mathrm{C}$ & $0-10$ \\
\hline Subbasin 2 & 262 & $\begin{array}{l}\text { Moderate cultivation, } \\
\text { Forest/Moderate cultivation, } \\
\text { Forest/Moderate cultivation, Forest }\end{array}$ & $\mathrm{C}$ & $0-10$ \\
\hline Subbasin 4 & 271 & $\begin{array}{l}\text { Intense cultivation/Intense } \\
\text { cultivation/Intense cultivation }\end{array}$ & $\mathrm{C}$ & $0-10$ \\
\hline Subbasin 6 & 1054 & $\begin{array}{l}\text { Intense Cultivation, Forest/Forest, } \\
\text { Moderate and Intense Cultivation/ } \\
\text { Forest, Moderate cultivation, Intense } \\
\text { Cultivation, and grass land }\end{array}$ & $\mathrm{C}, \mathrm{CL}$ & $0-10$ \\
\hline Subbasin 7 & 512 & $\begin{array}{l}\text { Intense Cultivation/ Intense } \\
\text { Cultivation, Moderate cultivation/ } \\
\text { Intense Cultivation, Moderate } \\
\text { cultivation }\end{array}$ & $\mathrm{C}$ & $0-10$ \\
\hline Subbasin 10 & 1237 & $\begin{array}{l}\text { Moderate cultivation, Intense } \\
\text { Cultivation/ Moderate cultivation, } \\
\text { grass, Intense Cultivation/Moderate } \\
\text { cultivation, grass, Intense Cultivation }\end{array}$ & CL,C & $0-10$ \\
\hline Subbasin 11 & 414 & $\begin{array}{l}\text { Intense Cultivation, forest Intense } \\
\text { Cultivation, forest, Moderate } \\
\text { cultivation/ Intense Cultivation, } \\
\text { forest, Moderate cultivation }\end{array}$ & $\mathrm{C}, \mathrm{L}$ & $0-10$ \\
\hline
\end{tabular}

$\mathrm{C}=$ Clay, $\mathrm{CL}=$ Clay loam.

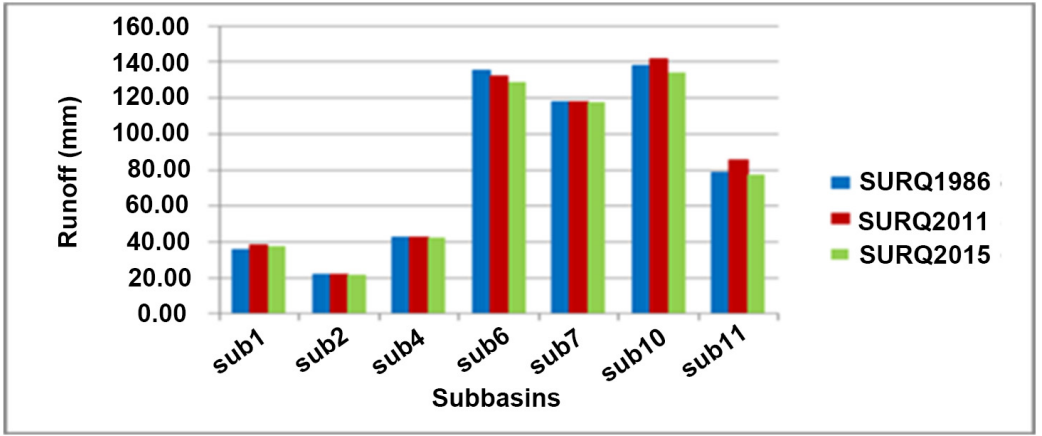

Figure 6. Surface runoff of sub basins for the three times land use/land covers.

this sub basin is characterized by poor drainage and low infiltration capacity. In other words, the runoff generated is relatively very high as a consequence of its cultivation lands. In contrast, the least runoff values are from subbasin2 in which substantial amounts of forest lands are preserved. Hence, this indicated that the natures of soil class, topography and land use type/cover have played dominant roles to affect the amount of surface runoffs in study catchment.

As it was already indicated in Figure 2 above, the amount of surface runoff 
was generally increased from 1986 to 2011, but decreased until 2013 at which it started the increasing trend. However, the base flow and water yield of the catchment generally decreased between 1986 and 2011 and then increased between 2011 and 2015 (Figure 7 and Figure 8). In addition to surface runoff, the hydrologic characteristics of the catchment are explained by base flow (groundwater outflow) and water yield. The base flow values range from $26.32 \mathrm{~mm}$ to $240.23 \mathrm{~mm}$ in subbasin 1 and subbasin 10 respectively. Similar to these hydrologic components, the water yield, which is roughly the sum of base flow and surface runoff, was estimated to be maximum within subbasin 10 and minimum within subbasin2.

Comparing the contributions of surface runoff and groundwater, the catchment water yield is largely dominated by base flow (57\%) than surface runoff $(41 \%)$. This in turn, determines the amount of soil water contents of the catchment which plays significant roles in agricultural productivity.

\subsection{Sedimentation and Soil Erosion in Melka Wakena Catchment}

Soil erosion is a worldwide environmental problem that degrades soil productivity and water quality, causes sedimentation of reservoirs and increases the probability of floods [24]. Most of the countries in the tropics have no appropriate and accurate soil erosion prediction model although the Soil Loss Estimation Model for Southern Africa (SLEMSA) and the Universal Soil Loss Equation (USLE) are used in different tropical countries [25].

SWAT employs MUSLE [26] to compute erosion caused by rainfalls and runoffs. This is a modified version of USLE developed by [17]. USLE predicts average annual gross erosion as a function of rainfall energy. In MUSLE, the rainfall energy factor is replaced with a runoff factor. This improves the sediment yield prediction, as the runoff is a function of antecedent moisture conditions and rainfall energy.

The tributaries contribute substantially to the siltation and sedimentation of the Melka Wakena catchment. Hence, the effects of this sedimentation have been observed affecting the optimum functioning of the dam and reservoir of the Melka Wakena hydropower.

The time series of simulated soil loss (sediment yield) from the Melka Wakena catchment is shown in Figure 9 and it indicated higher impacts from LULC of 2011 than the LULCs of 1986 and 2015. It was also observed that this trend is similar to that of the surface runoff. The unavailability of measured data made it impossible to validate the simulated soil loss and sediment yield results although the driving river discharges were calibrated and validated based on the observed data. The highest soil loss was $32.83 \mathrm{t} /$ ha which occurred in 1988 . The lowest was $5.41 \mathrm{t} / \mathrm{ha}$ and estimated in 2002. From the simulated results, it was also observed that the long-term mean soil loss is $20.22 \mathrm{t} / \mathrm{ha}$. There was sediment loss from each sub basins however, the loss was the highest in sub1 and sub11 sub basins (Figure 10). 


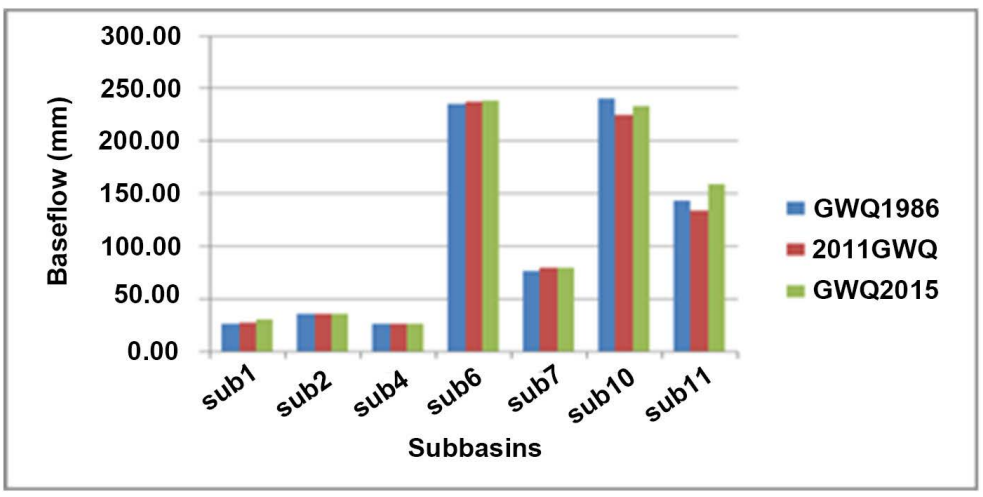

Figure 7. Base flow of sub basins for the three times LULC.

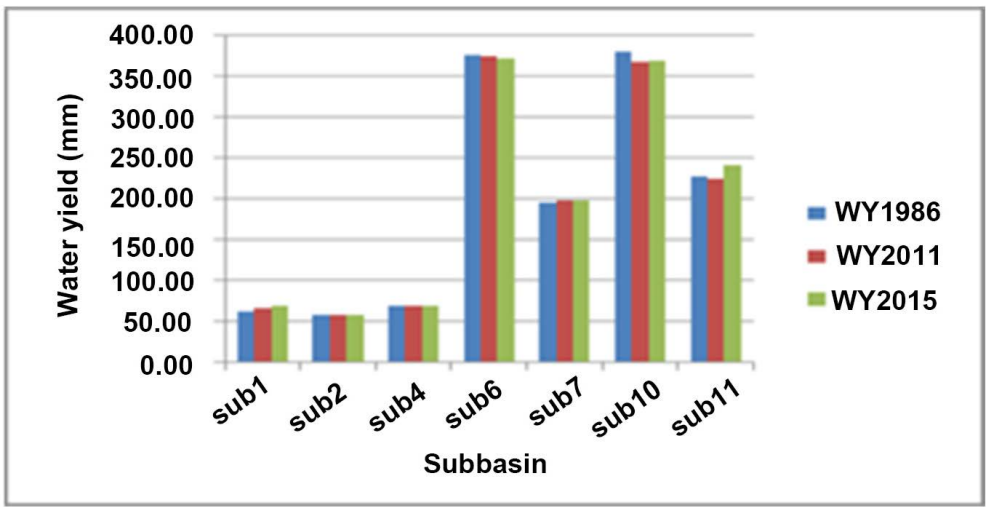

Figure 8. Water yield of the sub-basins for the three times LULC.

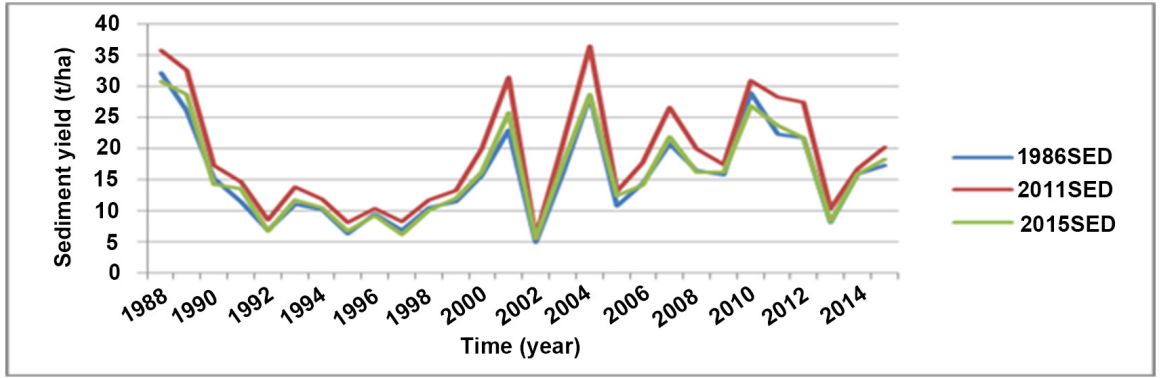

Figure 9. Simulated annual sediment yield (soil loss) from Melka Wakena catchment.

Based on the effects of LULC changes, the average soil loss (sediment yield) of the catchment was decreased in the early years (1986 to 1992) and then generally increased up to 2012 before it started the declining trend. There was high (R2 = $86 \%)$ correlation coefficient between surface runoff and soil loss. Figure 11 showed the level of impacts of runoff in generating sediments in the catchment. From this figure, it is observed that their relationship is statistically significant ( $\mathrm{p}$ $<0.01)$ and indicates the sediment yield generated was highly sensitive to little changes in surface runoff. In turn, these changes are directly attributed to the land use and land cover changes that caused the runoffs to change in both periods. In a general case, the three major factors that are considered in the model 


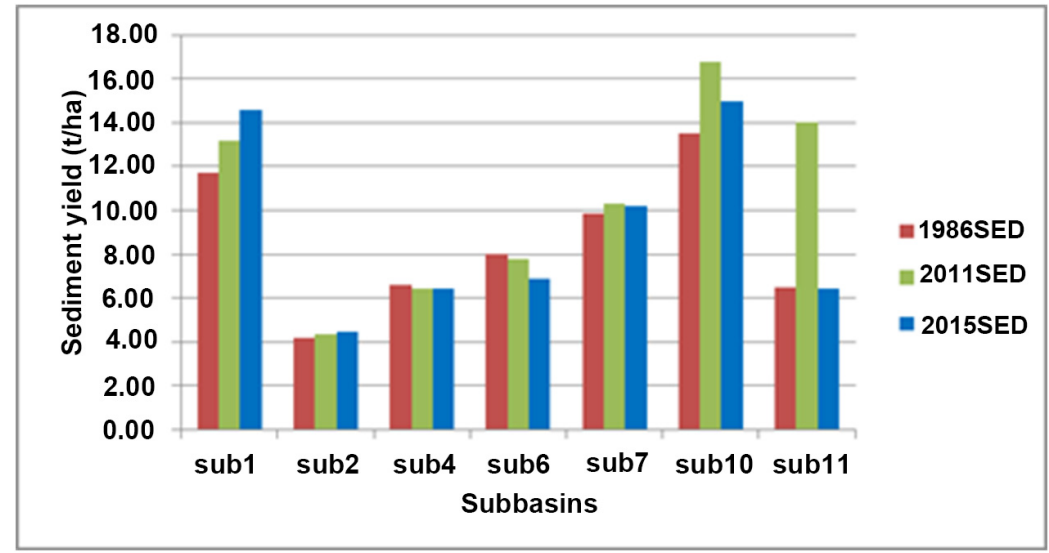

Figure 10. Average sediment yields of sub basins for the three times LULC.

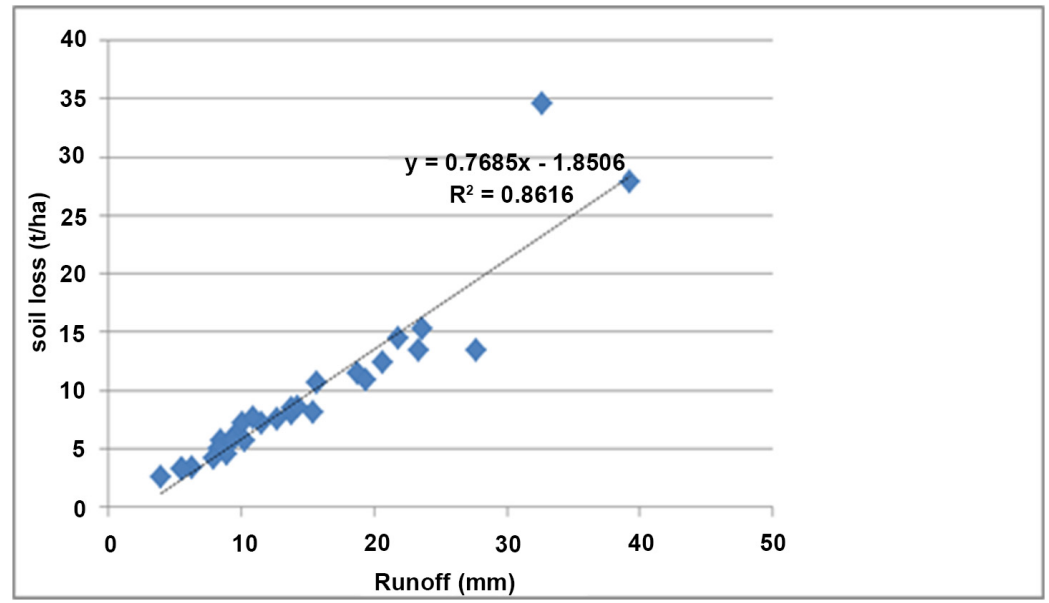

Figure 11. Relationship between surface runoff and soil loss (sediment yield).

to determine the sediment yield (soil loss) are soil type, land use/land cover, and slope. The simulated sediment yield and soil loss rates were generally higher in clay dominated soils, cultivated lands and steep slopes in the absence of conservation measures. These areas are also correspondent to areas where runoff generation was the highest in the catchment. In contrast, the estimated sediment yield and soil loss rates were generally lower in areas that are covered by forest, loam and sandy clay soils and flat slopes. During watershed delineation, it was estimated that more than $83 \%$ of the catchment is characterized by slopes that vary between 0 and 10. It was also analyzed that agricultural lands occupy more than $65 \%$ of the study catchment. Therefore, in assessing soil erosion process, the critical role is played by soil classes and land use/land covers.

Considering soil loss and sediment yield at sub basin scale, the highest soil loss is $16.78 \mathrm{t} / \mathrm{ha}$ and observed in subbasin 10 while the least is $4.17 \mathrm{t} / \mathrm{ha}$ which was estimated for subbasin2. Expectedly, these values are in correspondence with the maximum and minimum surface runoffs form these sub basins.

In subbasin 10 the sediment yield was increased in the first period (1986-2011) as a result of the conversion of forests to grass land and cultivations. However, it 
was decreased in the second period (2011-2015) which could be related to the introduction of soil and water conservation measures. The integrated effects of the various land use/land cover classes in subbasin 2 was the primary factor for small values of both surface runoff and sediment yields.

In the same way, sediment yields (soil loss) generated from different sub basins are also observed to vary based on the main physical characteristics of the sub basins and changes to surface runoffs of the particular sub basin. Accordingly, the average of the sediment yields of the seven sub basins vary from 8.62 to $10.40 \mathrm{t}$ /ha between 1986 and 2015. For instance, the runoff estimated in subbasin 1 was among the least, but, the sediment yield was a little bit smaller than values from subbasin10. In addition to the land use modifications (between moderate and intense cultivations), it was largely due to its small area coverage. Being dominated by cultivations, the role of land use/land cover is clearly expressed in sub-basin 4 in which insignificant change was observed between 1986 (6.59t/ha) and 2015 (6.42 t/ha).

Subbasin 6 is one of the largest sub basins and characterized by high drainage density and soil classes of clay and clay loam. It is the sub basin in which Adaba town is found and it has relatively appreciable amounts of forest covers. Similar to subbasin2, in addition to its size, the complex integration of the various land use/land cover classes could be responsible for the relatively smaller sediment yields. Its sediment yield is declined more especially after 2011 in relation to the beginning of soil and water conservation measures.

Subbasin7 includes some part of Kaka Mountain and it is characterized by clay and clay loam soils. The sediment yields of this sub basin were increased from 1986 to 2011 as result of modifications in moderate and intense cultivations. The higher values of sedimentation could be associated to the location of the sub basin that contributes to have slopes up 20\%. The mirror image of this sub basin is subbasin 11 which consists of Dodola town and it is characterized by dominant clay and loam soils.

The sediment yield of sub basin 11 was increased by more than $100 \%$ between 1986 and 2011 as a consequence of increases in agricultural lands at expense of grass land. However, in the second period, it was declined by similar percentage due to plantations in some part of the sub basin. Hence, based on their average values, the sediment yields generated from subbasin2, subbasin 4 and subbasin6, are smaller than the average while, subbasins 1 and subbasin 10 and subbasin 11 (in 2011) produced values much larger than the average value of the sub basins.

Based on the estimated sediment yields (soil loss rates), it could be possible to categorize the catchment into three severity classes. Accordingly, most of the catchment (50\%) was expected to face high erosion risks (10 - $15 \mathrm{t} / \mathrm{ha} / \mathrm{y})$. Similarly, about $6 \%$ and $41 \%$ of the catchment was impacted by low $(0-5 \mathrm{t} / \mathrm{ha} / \mathrm{y})$ and moderate (5 - $10 \mathrm{t} / \mathrm{ha} / \mathrm{y}$ ) erosion risks (Figure 12). Beside other factors, State farms surrounding the reservoir had their own role in contributing sediment to the reservoir/Melka Wakena dam (Figure 13). Generally, these variations in 


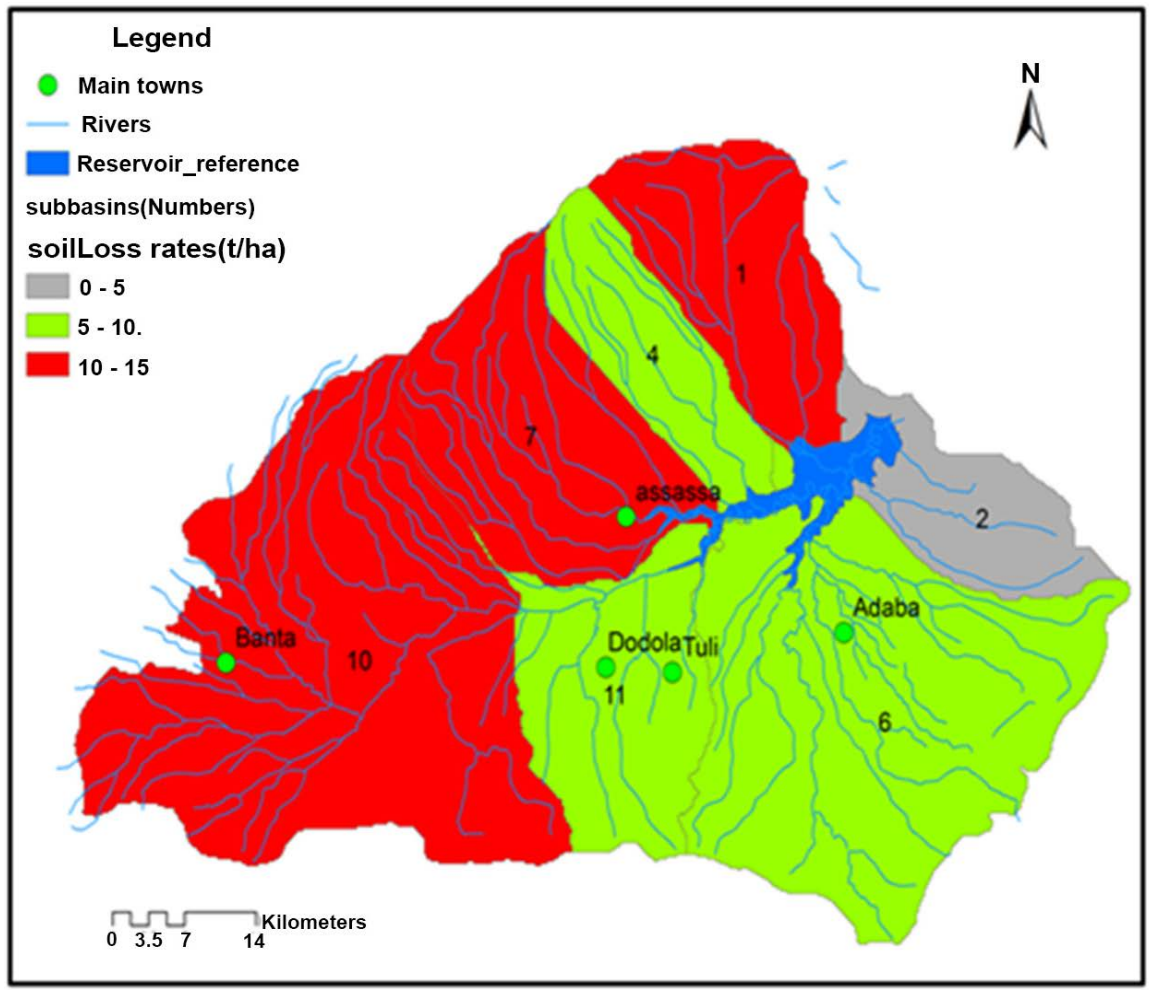

Figure 12. Soil loss (erosion rates) of the catchment.

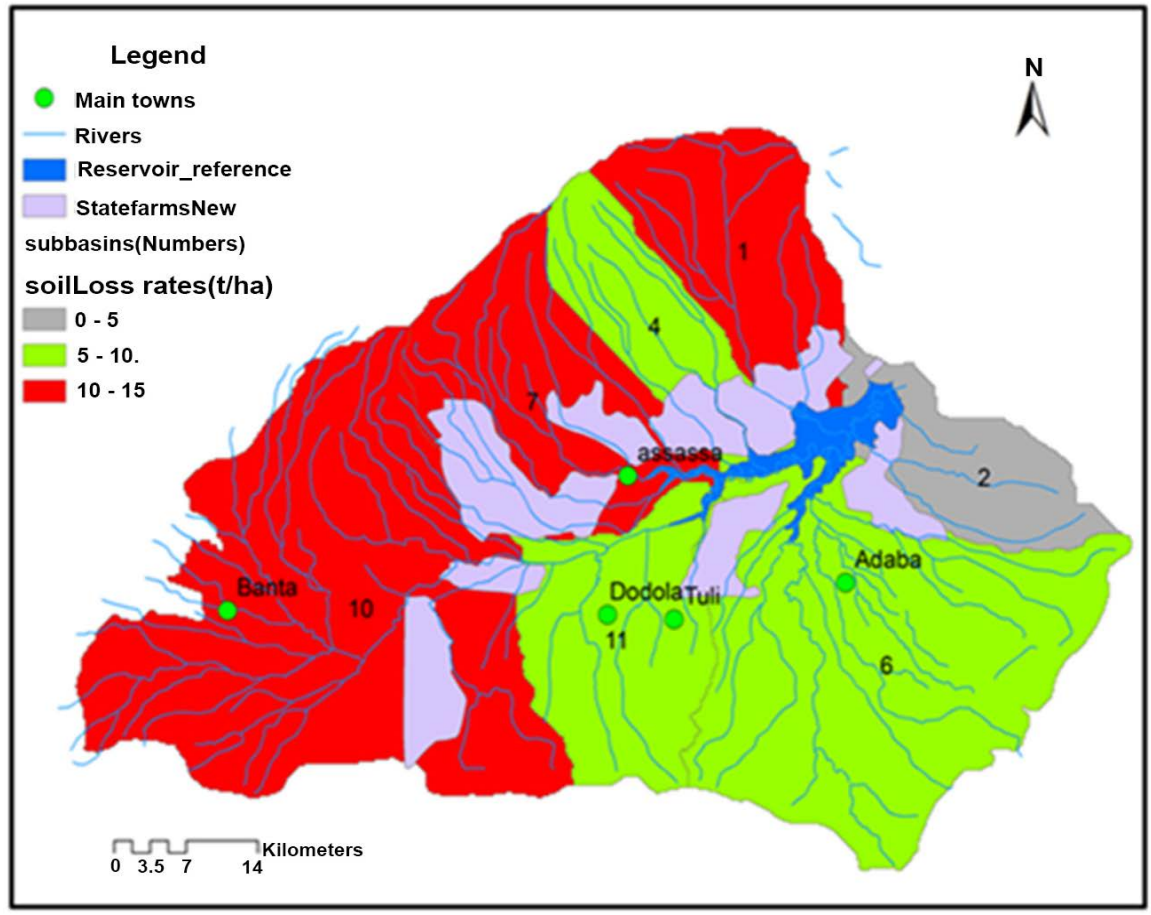

Figure 13. Locations of state farms shown on soil loss rate layer.

sediment yields and soil loss rates of the catchment and its sub basins for different periods are evident enough for the current level of land degradations. 
The impacts of the land degradations are being expressed at different aspects of the Melka Wakena hydropower and the various resources of the surrounding community. In this catchment, the main land use types contributing to sediment yields are intensified cultivations, and deforestations. It was also attributed to small changes inbuilt up areas although addressed implicitly. Thus, the effects of land use/land cover changes on the rate of erosion and sedimentation is more prevalent in sub basins having relatively high values of surface runoffs. Figure 14 shows the farmers village surrounding the hydroelectric dam/reservoir and their subsequent impacts on the dam and the dam itself impacts on them in different aspects.

\section{Conclusions and Recommendation}

\subsection{Conclusions}

The land use and land cover change analysis during the reference periods showed a significant conversion of natural forest and grazing land to cultivated land. This land use and land cover changes have been directly affecting the surface runoff and water yields of the catchment which this in turn is driving both landscape and the channel of river and stream. According to the result of the study, the annual surface runoff varied between $45.65 \mathrm{~mm}$ and $332.29 \mathrm{~mm}$. The result of the sediment yield (soil loss or erosion rate) analysis showed that there was a general increasing trend of soil loss from 1990 to 2012. The highest sediment yield was $32.83 \mathrm{t} / \mathrm{ha}$, the lowest $5.41 \mathrm{t} / \mathrm{ha}$, and the mean was $20.22 \mathrm{t} / \mathrm{ha}$ as estimated by the model. As a result of the effects of LULC changes, the average

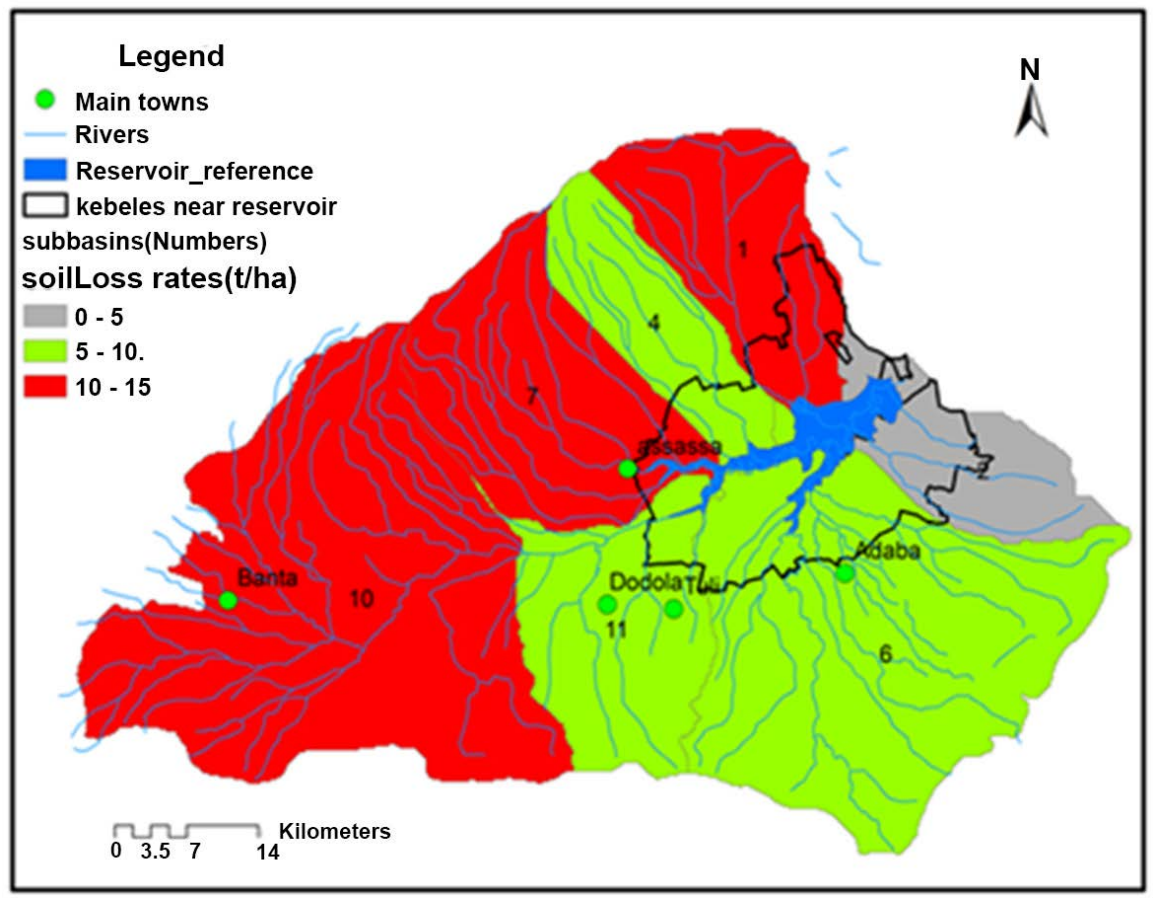

Figure 14. Kebeles near reservoir displayed on soil loss layer. 
sediment yield of the catchment was generally increased from 1986 to 2011, but decreased in the later time (2015).

With regard to the area coverage by level/severity of soil loss/erosion in $\mathrm{t} / \mathrm{ha} / \mathrm{y}$, about half $(50 \%)$ of the catchment was expected to face with high erosion risks (10 - $15 \mathrm{t} / \mathrm{ha} / \mathrm{y})$. Generally, as there have been variations in sediment yields (or soil loss rate) within the catchment and sub-basins for different periods, as a result there exists a high level of land degradation in the study catchment. Sedimentation caused by erosion has significantly affected the storage capacity of the Melka Wakena dam/reservoir. Therefore to mitigate this sedimentation processes and its impacts, integrated water shade management practice/sustainable soil and water conservation measures should be strengthened.

\subsection{Recommendation}

Based on the result obtained from the analysis of various data sources and conclusion the following recommendations have been drawn.

1) Sedimentation caused by erosion has significantly affected the storage capacity of the Melka Wakena dam/reservoir. Therefore, integrated water shade management practice/sustainable soil and water conservation measures should be strengthened to reduce both the on-site and off-site negative effects of soil erosion.

2) The decline in surface water levels over time in the study catchment is a result of many environmental degradation effects such as deforestation, overgrazing and inappropriate farming practices. Moreover, with increase in population, there is an increasing demand for more quantity of water for domestic consumption and agricultural production. Therefore local community needs to improve environmental protection, reduce water loss, increase water saving and efficiency.

3) Sustainable integrated watershed management practices should be practically implemented throughout the landscape of the catchment from upper to down streams. Above all, dam buffer area needs to be demarcated and protected from the current settlement; cultivation and overgrazing.

4) The utilization of irrigation on streams in study catchment is crucial in order to ensure food security and improve household income. On the other hand the prevalence of irrigation in the upper, middle and lower stream is significantly reducing the storage capacity of the reservoir and consequently power supply. Therefore to minimize the problem, another option has to utilize like underground water utilization through government financial and technical support.

\section{Acknowledgements}

The authors would like to thank Madda Walabu University and Federal water, irrigation and electric minister for providing the funds for this study. The authors are also grateful to West Arsi zone finance and economic development of- 
fice, community in study catchment for data provision, and Melka Wakena power substation for accommodation and transport services during the study periods.

\section{Conflicts of Interest}

The authors declare no conflicts of interest regarding the publication of this paper.

\section{References}

[1] Cerdà, A., Hooke, J., Romero-Diaz, A., Montanarella, L. and Lavee, H. (2010) Soil Erosion on Mediterranean Type Ecosystems. Land Degradation \& Development, 21, 71-74. https://doi.org/10.1002/ldr.968

[2] Abu-Hammad, A. and Tumeizi, A. (2012) Land Degradation, Socioeconomic and Environmental Causes and Consequences in the Eastern Mediterranean. Land Degradation \& Development, 23, 216-226. https://doi.org/10.1002/ldr.1069

[3] Al-Awadhi (2013) A Case Assessment of the Mechanisms Involved Inhuman-Induced Land Degradation in North Eastern Kuwait. Land Degradation\& Development, 24, 2-11. https://doi.org/10.1002/ldr.1090

[4] Temesgen, M., Hoogmoed, W., Rockström, J. and Savenije, H.H.G. (2009) Conservation Tillage Implements for Smallholder farmers in Semi-Arid Ethiopia. Soil \& Tillage Research, 10, 26-36. https://doi.org/10.1016/j.still.2008.10.026

[5] Haregeweyn, N. (2006) Reservoir Sedimentation in the North Ethiopian Highlands, Assessment and Modeling of Controlling Factors and Impacts. PhD Thesis, Department of Geography, Leuven.

[6] Bezuayehu, T. (2006) People and Dams, Environmental and Socio-Economic Changes Induced by a Reservoir in Fincha'a Watershed, Western Ethiopia. Tropical Resource Management Papers 75. Wageningen University, Wageningen.

[7] Wolka, K. (2012) Watershed Management: An Option to Sustain Dam and Reservoir Function in Ethiopia. Journal of Environmental Science and Technology, 5, 262-273. https://doi.org/10.3923/jest.2012.262.273

[8] Elias, E. (2003) Environmental Roles of Agriculture in Ethiopia. Paper Presented at The Role of Agriculture Project International Conference Sponsored by the Agricultural Economics Division, FAO, Rome.

[9] Amare, A. (2005) Study of Sediment Yield from the Watershed of (2005) Assessment of the Current Status of the Nile Basin Reservoir Sedimentation Problems. Nile Basin Capacity Building Network for River Engineering.

[10] Tamene, L. (2005) Reservoir Siltation in the Drylands of Northern Ethiopia, Causes, Source Areas and Management Options. PhD Thesis, Center for Development Research, University Bonn, Bonn.

[11] Chanasyk, D.S., Mapfumo, E. and Willms, W. (2003) Quantification and Simulation of Surface Runoff from Fescue Grassland Watersheds. Agricultural Water Management, 59, 137-153. https://doi.org/10.1016/S0378-3774(02)00124-5

[12] Central Statistical Agency of Ethiopia (CSA) (2008) Summary and Statistical Report of the 2007 Population and Housing Census. Addis Ababa.

[13] Arnold, J.G., Allen, P., Volk, M.M., Williams, J.R. and Bosch, D.D. (2010) Assessment of Different Representations of Spatial Variability on SWAT Model Perfor- 
mance. Transactions of the ASABE, 53, 1433-14435.

https://doi.org/10.13031/2013.34913

[14] Arnold, J.G., Srinivasan, R., Muttiah, R.S. and Williams, J.R. (1998) Large Area Hydrologic Modeling and Assessment Part 1, Model Development. Journal of the American Water Resources Association, 34, 73-89. https://doi.org/10.1111/j.1752-1688.1998.tb05961.x

[15] Arnold, J.G. and Allen, P.M. (1999) Automated Methods for Estimating Base Flow and Groundwater Recharge from Stream Flow Records. Water Resources Bulletin, 35, 411-424. https://doi.org/10.1111/j.1752-1688.1999.tb03599.x

[16] Williams, R. and Berndt, H.D. (1972) Sediment Yield Computed with Universal Equation. Journal of the Hydraulics Division, 98, 2087-2098.

[17] Wischmeier, W.H. and Smith, D.D. (1965) Predicting Rainfall Erosion Losses from Cropland East of the Rocky Mountains. USDA Agricultural Handbook 282. US Gov. Print Office, Washington DC.

[18] Wischmeier, W.H. and Smith, D.D. (1978) Predicting Rainfall Erosion Losses-A Guide to Conservation Planning. Agriculture Handbook No. 537, US Department of Agriculture, US Government Printing Office, Washington DC.

[19] Neitsch, S.I., Arnold, J.O., Kinrv, J.R. and Williams, J.R. (2005) Soil and Water Assessment Tool, Theoretical Documentation, Version 2005. USDA, Temple.

[20] Arnold, J., et al. (1998) Large Area Hydrologic Modeling and Assessment. Part I, Model Development. JAWRA, 34, 73-89.

[21] MacLeod, R.D. and Congalton, R.G. (1998) A Quantitative Comparison of Change-Detection Algorithm for Monitoring Eelgrass from Remotely Sensed Data. Photogrammetric Engineering and Remote Sensing, 64, 207-216

[22] Lambin, E.F., Geist, H.J. and Lepers, E. (2003) Dynamics of Land-Use and Land-Cover Change in Tropical Region. Annual Review of Environmental Resources, 28, 205-241. https://doi.org/10.1146/annurev.energy.28.050302.105459

[23] Houghton, R.A. and Hackler, J.L. (1995) Continental Scale Estimates of the Biotic Carbon Flux from Land Cover Change, 1850-1980. ORNL/CDIAC-79, NDP-050, Carbon Dioxide Information Analysis Center, Oak Ridge National Laboratory, U.S. Department of Energy, Oak Ridge.

[24] Ouyang, J. and Bartholic, D. (2001) Predicting Sediment Delivery Ratio in Saginaw Bay Watershed. The 22nd National Association of Environmental Professionals Conference Proceedings, Orlando, 19-23 May 1997, 659-671.

[25] Mulengera, M.K. (1999) Estimating the USLE-Soil Erodibility Factor in Developing Tropical Countries. Tropical Agriculture (Trinidad), 76, 17-22.

[26] Williams, J.R. (1975) Sediment-Yield Prediction with Universal Soil Equation Using Runoff Energy Factor. Present and Prospective Technology for Predicting Sediment Yield and Sources, Oxford, 28-30 November 1972, 244-252. 